38. Berry MN 1973 Energy demand of endogenous metabolism and gluconeogenesis in liver cells from normal and hyperthyroid rats. In: Lundquist $F$, Tygstrup N (eds) Regulation of Hepatic Metabolism. Munksgaard, Copenhagen, pp 568-578

39. Simmons MA, Battaglia FC, Meschia G 1979 Placental transfer of glucose. J Dev Physiol 1:227-243

40. Anand RS, Sperling MA, Ganguli S, Nathanielsz PW 1979 Bidirectional placental transfer of glucose and its turnover in fetal and maternal sheep. Pediatr Res 13:783-787

41. Garrow JS 1978 Factors affecting energy output. In: Energy Balance and Obesity in Man, 2nd ed. Elsevier-North Holland, Amsterdam, pp 95-98

42. Askanazi J, Rosenbaum SH, Hyman AI, Silverberg PA, Milic-Emili J, Kenney JM 1980 Respiratory changes induced by the large glucose loads of total parenteral nutrition. JAMA 243:1444-1447
43. Thiebaud D, Schutz Y, Acheson K, Jacot E, DeFronzo RA, Felber JP, Jaquier E 1983 Energy cost of glucose storage in humans and subjects during glucoseinsulin infusions. Am J Physiol 244:E216-E221

44. Welle S, Lilavivat U, Campbell RG 1981 Thermic effect of feeding in man: increased plasma norepinephrine levels following glucose but not protein or fat consumption. Metabolism 10:953-958

45. Carson BS, Philipps AF, Simmons MA, Battaglia FC, Meschia G 1980 Effects of a sustained insulin infusion upon glucose uptake and oxygenation of the ovine fetus. Pediatr Res 14:147-152

46. Milley JR, Rosenberg AA, Philipps AF, Molteni RA, Jones MD Jr, Simmons MA 1984 The effect of insulin on ovine fetal oxygen extraction. Am J Obstet Gynecol 149:673-678

47. Szabo AJ, Grimaldi RD 1970 The effect of insulin on glucose metabolism of the incubated human placenta. Am J Obstet Gynecol 106:75-78

\title{
Long-Chain Acyl Coenzyme A Dehydrogenase Deficiency: An Inherited Cause of Nonketotic Hypoglycemia
}

\author{
DANIEL E. HALE, MARK L. BATSHAW, PAUL M. COATES, FRANK E. FRERMAN,
} STEPHEN I. GOODMAN, INDERJIT SINGH, AND CHARLES A. STANLEY

\begin{abstract}
The Children's Hospital of Philadelphia and the Department of Pediatrics, University of Pennsylvania School of Medicine, Philadelphia, Pennsylvania 19104 [D.E.H., P.M.C., C.A.S.]; Department of Pediatrics and Neurology and the John F. Kennedy Institute, Johns Hopkins Medical Institutions, Baltimore, Maryland 21205 [M.L.B. I.S.]; Department of Microbiology, Medical College of Wisconsin, Milwaukee, Wisconsin 53226 [F.E.F.]; Department of Pediatrics, University of Colorado School of Medicine, Denver, Colorado 80262 [S.I.G.]
\end{abstract}

\begin{abstract}
Three children from unrelated families presented in early childhood with hypoglycemia and cardiorespiratory arrests associated with fasting. Significant hepatomegaly, cardiomegaly, and hypotonia were present at the time of initial presentation. Ketones were not present in the urine at the time of hypoglycemia in any patient; however, dicarboxylic aciduria was documented in one patient at the time of the acute episode and in two patients during fasting studies. Total plasma carnitine concentration was low with an increased esterified carnitine fraction. These findings suggested a defect in mitochondrial fatty acid oxidation, and specific assays were performed for the acyl coenzyme $A(\mathrm{CoA})$ dehydrogenases. These analyses showed that the activity of the long-chain acyl CoA dehydrogenase was less than $10 \%$ of control values in fibroblasts, leukocytes, and liver tissue. Activities of the medium-chain, short-chain, and isovaleryl CoA dehydrogenases were not different from control values. With cultured fibroblasts, $\mathrm{CO}_{2}$ evolution from long-chain fatty acids was significantly reduced, while $\mathrm{CO}_{2}$ evolution from mediumchain and short-chain fatty acids was comparable to control values-findings consistent with a defect early in the $\beta$ -
\end{abstract}

Received November 21, 1984; accepted February 27, 1985.

Reprint requests Daniel E. Hale, M.D., Division of Endocrinology/Diabetes, The Children's Hospital of Philadelphia, 34th and Civic Center Boulevard, Philadelphia, PA 19104.

Supported by NIH Grants PO1-NS 17752, 5-K01-AM 01226, HD 10981, 5 T32-AM07314, RR-00240, GM 25494, AM 15527, HD 16600, HD 08315 , RR00052, and a grant from the National Reye's Syndrome Foundation of Bryan, $\mathrm{OH}$. oxidation sequence. Studies of acyl CoA dehydrogenase activities in fibroblasts and leukocytes from parents of the patients showed levels of long-chain acyl $\mathrm{CoA}$ dehydrogenase activity intermediate between affected and control values and indicated an autosomal recessive form of inheritance of this enzymatic defect. These results describe a previously unrecognized metabolic disorder of fatty acid oxidation due to a deficiency of the long-chain acyl $\mathrm{CoA}$ dehydrogenase which may present in early childhood with disastrous consequences. This diagnosis should be considered in children who present with nonketotic hypoglycemia, carnitine insufficiency, and inadequately explained cardiorespiratory arrests. (Pediatr Res 19: 666-671, 1985)

\section{Abbreviations}

CoA, coenzyme A

ETF, electron transfer flavoprotein

A heterogeneous group of patients has been described with fasting intolerance presumed to result from defects in fatty acid metabolism (1-8). This conclusion has been drawn from a number of laboratory findings, including markedly elevated free fatty acids without consequent elevation of ketone bodies in the presence of hypoglycemia, and dicarboxylic aciduria. In some 
cases a specific enzymatic defect has been identified, while in other cases the site of defect remains to be elucidated. Herein, we report three children with clinical and laboratory findings consistent with a defect in fatty acid oxidation, and identify the site of defect as the long-chain acyl CoA dehydrogenase, the first intramitochondrial step in the oxidation of the long-chain fatty acids.

\section{CASE REPORTS}

Patient R-1 was the $36 \mathrm{wk}$, appropriate-for-gestational-age product of a gravida 2 , para 0 , abortus 1,39 -yr-old mother. He was born by caesarian section. The parents are third cousins. At $36 \mathrm{~h}$ of age the child had a cardiorespiratory arrest and was successfully resuscitated. No cause was found for this arrest, and the child was discharged home at 10 days of age. He gained weight poorly and was noted to have frequent episodes of emesis. At 6 wk of age, grade III gastroesophageal reflux was documented and the child was placed on an appropriate achalasia regimen. At $10 \mathrm{wk}$ of age the child developed a viral-like illness with diarrhea, decreased appetite, and lethargy and was placed on a clear liquid diet. Over the next $36 \mathrm{~h}$, he became increasingly obtunded and was hospitalized. Examination revealed a hypotonic, unresponsive infant with the liver palpable $5 \mathrm{~cm}$ below the right costal margin. The serum glucose was $25 \mathrm{mg} / \mathrm{dl}$ and no ketones were present in the urine. The urine was not examined for dicarboxylic acids. Other laboratory results included a serum bicarbonate of $18 \mathrm{mEq} / \mathrm{liter}$, blood ammonia of $180 \mu \mathrm{mol} / \mathrm{liter}$ (normal $<40 \mu \mathrm{mol} / \mathrm{liter}$ ), and normal liver function tests. With intravenous fluids and glucose, the child showed slight initial improvement, but $12 \mathrm{~h}$ after hospitalization he had a cardiorespiratory arrest requiring resuscitation and ventilation. A chest $\mathrm{x}$-ray showed cardiac enlargement and a subsequent echocardiogram showed marked hypertrophic cardiomyopathy. A liver biopsy showed a large quantity of macrovesicular fat. Glycogen storage diseases types I, III, and VI were ruled out by normal enzyme activities in a liver biopsy specimen (Dr. Barbara Brown, St. Louis, MO). Serum carnitine was found to be $10 \mu \mathrm{mol}$ liter (normal 40-60 $\mu \mathrm{mol} / \mathrm{liter}$ ) and was $100 \%$ esterified (normal 10 $20 \%$ ). Liver carnitine was $110 \mathrm{nmol} / \mathrm{g}$ wet weight (normal 730 $1800 \mathrm{nmol} / \mathrm{g})$. The patient was begun on oral carnitine $(100 \mathrm{mg} /$ $\mathrm{kg} /$ day) and a high carbohydrate, low fat diet. Gradual improvement was seen on this regimen. By the age of 12 months, cardiac hypertrophy resolved. The child is microcephalic and hypotonic with normal reflexes. A CT scan obtained to evaluate the microcephaly showed mild bilateral cerebral atrophy. Developmental testing done at 36 months of age showed his gross motor developmental quotient to be about 50 and his social and verbal developmental quotient to be between 60 and 70 .

Patient A-1 was the term product of a gravida 2, para 1, 18yr-old mother. The parents are not related. The child was well until 4 months of age when she developed postprandial vomiting unassociated with fever or diarrhea. After $48 \mathrm{~h}$ she was admitted to a local hospital with lethargy and hypotonia. This rapidly progressed to hypotension and respiratory arrest. Physical examination revealed an appropriate-sized child who was responsive only to painful stimuli. The liver was palpable $7 \mathrm{~cm}$ below the right costal margin. Laboratory evaluation showed a serum glucose of $20 \mathrm{mg} / \mathrm{dl}$, an absence of ketones in serum and urine, an arterial $\mathrm{pH}$ of 7.30 , serum bicarbonate of $18 \mathrm{mEq} / \mathrm{liter}$, and a serum ammonia of $70 \mu \mathrm{mol} /$ liter. Liver function tests were mildly abnormal with SGOT $87 \mathrm{IU} /$ liter, SGPT $64 \mathrm{IU} /$ liter, and alkaline phosphatase $55 \mathrm{IU} /$ liter. Prothrombin time and partial thromboplastin time were normal. Cardiac enlargement was noted on a chest $\mathrm{x}$-ray and a subsequent echocardiogram demonstrated significant cardiac hypertrophy and a decreased left ventricular ejection fraction. Treatment with $20 \%$ dextrose resulted in rapid clinical improvement within $24 \mathrm{~h}$. Subsequent metabolic investigations revealed a serum carnitine of $28 \mu \mathrm{mol} /$ liter of which $48 \%$ was esterified. During a fasting study the serum glucose fell from 100 to $45 \mathrm{mg} / \mathrm{dl}$ over $12 \mathrm{~h}$, and the urine showed peaks of suberic and sebacic acid by gas liquid chromatography; a $\beta$-hydroxybutyrate peak was not present. The organic acid peaks disappeared on a normal feeding regimen. Because these findings suggested a defect in fatty acid metabolism, she was discharged on frequent high carbohydrate feedings. She remained asymptomatic for the next 2 months with gradual resolution of the cardiomegaly. Mild hypotonia with normal reflexes persisted. Intellectual function tested at 6 months of age was normal. At $6 \frac{1}{2}$ months of age, she had another episode of vomiting and lethargy associated with a viral illness and was admitted to a local hospital where she was treated with oral clear liquids. She died during her first night of hospitalization. No performed.

Patient $\mathrm{J}-1$ was the $3 \mathrm{lb} 7 \mathrm{oz}$ product of a 32-wk gestation complicated by maternal toxemia and placenta previa. She was delivered by an emergency caesarian section with Apgars of 1 and 3. The parents are not related. The child required ventilation for several hours. At 4 days of age she developed necrotizing enterocolitis and was treated with 10 days of antibiotics and hyperalimentation. She was noted to be microcephalic and a subsequent CT scan showed marked changes in the brain consistent with perinatal asphyxia. She gained weight slowly and had frequent feeding problems. She was discharged home at $5 \mathrm{wk}$ of age but she did not thrive and continued to have recurrent emesis. At 5 months of age she developed persistent vomiting without diarrhea or fever. She became obtunded and on arrival at the hospital she had a grand mal seizure. The blood glucose was $25 \mathrm{mg} / \mathrm{dl}$ and she was treated with intravenous glucose and phenobarbital. Hepatomegaly was present and the SGPT was elevated to $250 \mathrm{IU} /$ liter. She improved gradually and was placed on a high caloric formula (Similac 24) supplemented with medium-chain triglycerides. On this regimen she appeared to grow better although development continued to be slow. At 10 months of age, she again developed persistent vomiting accompanied by diarrhea and was rehospitalized. The blood glucose was found to be $51 \mathrm{mg} / \mathrm{dl}$ and intravenous glucose was begun. Additional laboratory data obtained at that time included a serum bicarbonate of $13 \mathrm{mEq} / \mathrm{liter}$, a blood ammonia of $45 \mu \mathrm{mol} / \mathrm{liter}$, and the absence of ketones in the urine. During a fasting study, performed 4 days later, her blood glucose fell to $40 \mathrm{mg} / \mathrm{dl}$ at $6 \mathrm{~h}$. In the urine no ketones were present; however, suberic and sebacic acids were increased 3-fold. Suberylglycine and hexanoylglycine were not present in the urine. The serum carnitine was $14 \mu \mathrm{mol} /$ liter, which was $96 \%$ esterified. Liver biopsy showed macrovesicular fatty infiltration of the liver and moderate periportal fibrosis. An echocardiogram revealed biventricular hypertrophy. The child was begun on oral carnitine $(50 \mathrm{mg} / \mathrm{kg} /$ day) and a high carbohydrate diet. Gradual improvement in linear growth and weight was seen on this regimen. By the age of 15 months, cardiac hypertrophy resolved. Modest hepatomegaly was still present. Hypotonia was also present but reflexes were normal and symmetrical. Developmental evaluation performed at 15 months of age revealed the child to be functioning at the level of a 2-3 month old.

\section{MATERIALS AND METHODS}

Skin biopsies for fibroblast culture were obtained from patients A-1, R-1, and their parents. Control fibroblast cultures were obtained from the Human Genetic Cell Mutant Respository, Institute for Medical Research, Camden, NJ (GM 10, GM 38, GM 41) and from the Cell Center, Human Genetics Center, University of Pennsylvania. Cells between the 4th and 15th passages were used for the studies described. Fibroblast cultures were grown in RPMI 1640 medium supplemented with $10 \%$ fetal bovine serum. Monolayers were harvested by trypsinization and washed with RPMI 1640 medium. Pelleted cells were either used immediately for fatty acid oxidation studies or frozen at $-20^{\circ} \mathrm{C}$ for subsequent assay of acyl $\mathrm{CoA}$ dehydrogenase activities. 
Mononuclear leukocytes from patients R-1, J-1, and their parents were isolated from 8 to $30 \mathrm{ml}$ of chelated blood as previously described by Coates et al. (9). Contaminating erythrocytes were removed by hypotonic lysis. Cells were pelleted and frozen at $-20^{\circ} \mathrm{C}$ for subsequent assay of acyl CoA dehydrogenase activities.

Necropsy liver obtained within $4 \mathrm{~h}$ of death was available on patient A-1. Control liver specimens were obtained on three patients by open biopsy: one for definitive diagnosis of glycogen storage disease, one for unexplained hepatomegaly, and one for a suspected defect in fatty acid metabolism. Specimens were stored at $-70^{\circ} \mathrm{C}$ until assayed for acyl CoA dehydrogenase activities. Frozen tissues (liver, leukocytes, fibroblasts) showed no loss of acyl CoA dehydrogenase activities for at least 3 months.

Acyl CoA substrates were purchased from P. L. Biochemicals. Glucose oxidase, type V from Aspergillus niger, and bovine liver catalase were obtained from Sigma Chemical Co. Pig liver ETF was prepared by the procedure of Husain and Steenkamp (10). The $A_{270 n m}: A_{436 n m}$ of the preparation was 6.1. The concentration of ETF was determined spectrophotometrically at $436 \mathrm{~nm}, \mathrm{E}=$ $13.4 \mathrm{mM}^{-1}(11)$. All other chemicals were obtained from commercial sources and were the best grade available.

Acyl CoA dehydrogenase activities. The activities of the longchain, medium-chain, and short-chain acyl CoA dehydrogenases and isovaleryl $\mathrm{COA}$ dehydrogenase were determined using a fluorometric assay based on the loss of fluorescence of ETF as it is reduced (12). With this assay it is not necessary to isolate and purify the enzyme(s) of interest; hence it is possible to assay for each enzyme in 20-200 $\mu \mathrm{g}$ of tissue. Due to the specificity of the acyl CoA dehydrogenase-acyl CoA-ETF interaction, there is no interference of other dehydrogenases with this assay.

Tissue was thawed in $1.0 \mathrm{ml}$ of $25 \mathrm{mM} \mathrm{KPO}_{4}$ buffer, $\mathrm{pH} 7.4$, containing $0.2 \mathrm{mM}$ EDTA and disrupted by sonication $(3 \times 10$ $\mathrm{s}, 30 \mathrm{~W})$ at $4^{\circ} \mathrm{C}$. This was then centrifuged at $40,000 \times g$ for 30 min and the supernatant was assayed for acyl $\mathrm{CoA}$ dehydrogenase activity fluorometrically, exciting ETF flavin at $342 \mathrm{~nm}$ and measuring emission at $496 \mathrm{~nm}$. The final assay mixture contained, in a total volume of $1.5 \mathrm{ml}, 20 \mathrm{mM}$ Tris, $\mathrm{pH} 8.0,18.5$ $\mathrm{mM}$ glucose, $2 \mu \mathrm{M}$ ETF, $20 \mathrm{U}$ glucose oxidase, $0.5 \mathrm{U}$ catalase, $50 \mu \mathrm{M}$ acyl CoA substrate, and 20-200 $\mu \mathrm{g}$ supernatant protein. The mixture containing buffer, glucose, ETF, acyl CoA substrate, and catalase was placed in a sealed cuvette, made anaerobic by 10 cycles of alternate evacuation and purging with argon and was left under slight positive pressure. Glucose oxidase was added by syringe and the mixture was preincubated for $10 \mathrm{~min}$ at $30^{\circ}$ C. The reaction was initiated by the addition of a small volume of the tissue supernatant. Assays for each dehydrogenase were carried out at three or more protein concentrations. With patient fibroblasts, acyl CoA dehydrogenase activities were determined on at least three different cell pellets. Enzyme activity was expressed as nmol ETF reduced per minute per milligram supernatant protein. Protein content was determined by the method of Lowry et al. (14).

Fatty acid oxidation in fibroblasts. Fatty acid oxidation was measured by incubating freshly-harvested fibroblasts with ${ }^{14} \mathrm{C}$ labeled fatty acids in $3.0 \mathrm{ml}$ Krebs-Ringer bicarbonate buffer,

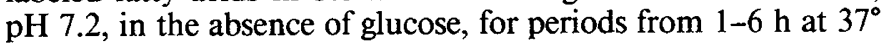

$C$ in polypropylene bottles sealed with rubber stoppers and equipped with hanging center wells (Kontes Scientific). Incubation contained $2.5-10 \times 10^{5}$ cells. Blank vessels contained no cells. The fatty acids tested, their source, and their final specific activity were as follows: $\left[1-{ }^{14} \mathrm{C}\right]-$ and $\left[{ }^{14} \mathrm{C}(\mathrm{U})\right]$-palmitate and $[1-$ $\left.{ }^{14} \mathrm{C}\right]$-octanoate (New England Nuclear, $0.3 \mathrm{mCi} / \mathrm{mmol}$ ); $\left[1-{ }^{14} \mathrm{C}\right]$ butyrate (New England Nuclear, $1.6 \mathrm{mCi} / \mathrm{mmol}$ ); $\left[16-{ }^{14} \mathrm{C}\right]-\mathrm{pal}-$ mitate (Research Products International, $0.3 \mathrm{mCi} / \mathrm{mmol}$ ). The final concentration of palmitate and octanoate was $2.5 \mathrm{mM}$; butyrate was $10 \mathrm{mM}$. The fatty acid:bovine serum albumin molar ratio was $4: 1$. Assays were run in triplicate and reactions were terminated by adding $1.0 \mathrm{ml} 1 \mathrm{~N} \mathrm{H}_{2} \mathrm{SO}_{4}$. Hyamine hydroxide $(0.3 \mathrm{ml})$ was added to the center well and ${ }^{14} \mathrm{CO}_{2}$ was trapped by incubating the flasks for $1 \mathrm{~h}$ at room temperature. Radioactivity was measured by liquid scintillation counting in $80 \%$ Econofluor (New England Nuclear): 20\% absolute ethanol (vol:vol). Results were corrected to total $\mathrm{CO}_{2}$ production and expressed as nmol $\mathrm{CO}_{2}$ produced per $10^{6}$ cell per hour.

Statistical analysis of data. Results were expressed as mean \pm SD and differences between means were evaluated by Student's $t$ test.

\section{RESULTS}

The similarities between these patients and those with the medium-chain acyl CoA dehydrogenase deficiency (non-ketotic hypoglycemia with fasting, carnitine deficiency and dicarboxylic aciduria) led to an evaluation of the activities of the acyl CoA dehydrogenases involved in fatty acid oxidation. Table 1 shows the activities of the long-chain, medium-chain and short-chain acyl CoA dehydrogenases and the isovaleryl CoA dehydrogenase in cultured skin fibroblasts from R-1, A-1 and their parents. Long-chain acyl CoA dehydrogenase activity was less than $10 \%$ of the control value in both patients. The activity of the longchain acyl CoA dehydrogenase in fibroblasts from their parents was $63 \%$ of the values in controls. Fibroblasts from both patients and their parents had normal activities of the medium-chain and short-chain acyl CoA dehydrogenases and of the isovaleryl $\mathrm{CoA}$ dehydrogenase.

Table 2 shows the activities of the acyl CoA dehydrogenases in mononuclear leukocytes from $\mathrm{R}-1, \mathrm{~J}-1$, and their parents. The levels of enzyme activities were similar to those found in cultured fibroblasts. The patients had less than $10 \%$ of control values for long-chain acyl COA dehydrogenase activity. The parents were again found to have long-chain acyl CoA dehydrogenase activity intermediate between their child and controls. The activities of the other acyl CoA dehydrogenases in R-1, J-1, and their parents were similar to controls.

The activities of the acyl CoA dehydrogenases were also determined using liver tissue obtained within $4 \mathrm{~h}$ of death from A-1. Long-chain acyl COA dehydrogenase activity was $9.14 \mathrm{nmol} /$ $\mathrm{min} / \mathrm{mg}$ in the liver specimen from A-1, which was $10 \%$ of the value obtained from control livers $(91 \pm 13 \mathrm{nmol} / \mathrm{min} / \mathrm{mg}$ protein). In control liver, the level of long-chain acyl CoA dehydrogenase activity was 30 -fold greater than in control fibroblasts and leukocytes. Activities of the medium- and short-chain acyl CoA dehydrogenases in liver tissue from A- 1 were similar

Table 1. Acyl CoA dehydrogenase activities in fibroblasts ( $\mathrm{nmol} \mathrm{ETF} \mathrm{reduced/min/mg} \mathrm{protein)}$

\begin{tabular}{lllll}
\hline & \multicolumn{1}{c}{$\begin{array}{c}\text { Long-chain } \\
\left(\mathrm{C}_{16} \mathrm{CoA}\right)\end{array}$} & $\begin{array}{c}\text { Medium-chain } \\
\left(\mathrm{C}_{8} \mathrm{CoA}\right)\end{array}$ & $\begin{array}{c}\text { Short-chain } \\
\left(\mathrm{C}_{4} \mathrm{CoA}\right)\end{array}$ & $\begin{array}{c}\text { Isovaleryl } \\
\text { (iv CoA })\end{array}$ \\
\hline Control $(n)$ & $2.24 \pm 0.26(14)$ & $3.79 \pm 0.57(14)$ & $2.24 \pm 0.22(5)$ & $1.79 \pm 0.22(4)$ \\
R-1 & $0.18^{*}$ & 3.22 & 2.42 & 2.04 \\
A-1 & $0.20 \dagger$ & 3.42 & 2.16 & 1.94 \\
Parents $(n=4)$ & $1.67 \pm 0.27 \pm$ & $3.68 \pm 0.67$ & $2.35 \pm 0.44$ & $1.66 \pm 0.34$ \\
\hline
\end{tabular}

\footnotetext{
* Mean of three experiments.

$\dagger$ Mean of four experiments.

$\ddagger p<0.01$ compared to controls.
} 
Table 2. Acyl CoA dehydrogenase activities in mononuclear leukocytes (nmol ETF reduced/min/mg protein)

\begin{tabular}{lllll}
\hline & \multicolumn{1}{c}{$\begin{array}{c}\text { Long-chain } \\
\left(\mathrm{C}_{16} \mathrm{CoA}\right)\end{array}$} & $\begin{array}{c}\text { Medium-chain } \\
\left(\mathrm{C}_{8} \mathrm{CoA}\right)\end{array}$ & $\begin{array}{c}\text { Short-chain } \\
\left(\mathrm{C}_{4} \mathrm{CoA}\right)\end{array}$ & $\begin{array}{c}\text { Isovaleryl } \\
(\mathrm{iv} \text { CoA })\end{array}$ \\
\hline Control $(n)$ & $2.11 \pm 0.30(15)$ & $4.12 \pm 0.48(14)$ & $2.09 \pm 0.33(13)$ & $1.49 \pm 0.22(4)$ \\
R-1 & $0.27^{*}$ & 3.94 & 2.44 & 1.44 \\
$\mathrm{~J}-1$ & $0.21 \dagger$ & 4.38 & 2.51 & \\
Parents $(n=4)$ & $1.39 \pm 0.29 \ddagger$ & $4.08 \pm 0.51$ & $2.54 \pm 0.30$ & \\
\hline
\end{tabular}

* Mean of six determinations.

$\dagger$ Mean of four determinations.

$\ddagger p<0.01$ compared to controls.

to control values. Due to concern about a possible selective loss of long-chain acyl CoA dehydrogenase activity in the necropsy liver, the effect of delay between the time of death and the time of collection of liver tissue was evaluated using guinea pig liver (Hale DE, unpublished experiments). The animals were anesthetized, the abdomen was opened, and a liver biopsy was obtained. The animal was then killed and the liver was allowed to remain in situ. At hourly intervals, for $6 \mathrm{~h}$, additional liver biopsies were obtained and frozen. These studies showed a gradual timedependent loss of all of the acyl CoA dehydrogenase activities $(3-5 \% / h)$, but this effect was clearly not selective for the longchain acyl CoA dehydrogenase.

The functional effect of the deficiency of long-chain acyl CoA dehydrogenase on fatty acid oxidation was examined in cultured skin fibroblasts from patient R-1. Figure 1 shows a representative time course of palmitate oxidation by fibroblasts from patient $\mathrm{R}-1$ and a control subject with $\left[{ }^{14} \mathrm{C}(\mathrm{U})\right]$-palmitate as a marker. Rates of oxidation were linear between 2 and $5 \mathrm{~h}$ in the control fibroblasts. The rate of oxidation of palmitate by fibroblasts from $\mathrm{R}-1$ was less than $20 \%$ of the control. Table 3 compares the rate of $\mathrm{CO}_{2}$ production by fibroblasts from $\mathrm{R}-1$ and controls using palmitate labeled at different positions and $\left[1-{ }^{14} \mathrm{C}\right]$-labeled shortand medium-chain length fatty acids. The apparent rate of palmitate oxidation was significantly less than control values and was dependent on the position of the label, being $20 \%$ of control with $\left[{ }^{14} \mathrm{C}(\mathrm{U})\right]$-palmitate, $51 \%$ of control with $\left[1-{ }^{14} \mathrm{C}\right]$-palmitate, and $12 \%$ of control with $\left[16-{ }^{14} \mathrm{C}\right]$-palmitate. This difference may reflect some nonmitochondrial oxidation of the carboxyl-terminal end of long-chain fatty acids. The rates of octanoate and butyrate oxidation were within the control range in fibroblasts from $\mathrm{R}-1$ and confirmed that $\beta$-oxidation was intact beyond the point of entry of medium-chain fatty acids into this pathway.

Finally, the activities of the acyl CoA dehydrogenases were determined in fibroblasts from one $(\mathrm{HC})$ of two siblings described by Naylor et al. (6). Clinically this child resembled our three patients, with repeated episodes of unexplained lethargy and coma associated with fasting, hypoglycemia, and dicarboxylic aciduria, but without ketonemia. Cardiac hypertrophy was not noted in this patient although it was noted in her younger sibling who had similar clinical findings. Long-chain acyl CoA dehydrogenase activity was $0.19 \mathrm{nmol}$ ETF reduced per minute per milligram protein ( $10 \%$ of control), while the medium-chain and short-chain acyl CoA dehydrogenase activities were comparable to control values.

\section{DISCUSSION}

These studies describe a disorder of mitochondrial fatty acid $\beta$-oxidation caused by an inherited deficiency of long-chain acyl CoA dehydrogenase activity. The clinical features of three affected patients included episodes of illness provoked by fasting stress with coma, hepatomegaly, cardiomyopathy, and muscle weakness. Metabolic features included nonketotic hypoglycemia and decreased levels of carnitine in both plasma and tissues. Under the stress of fasting, increased urinary excretion of dicarboxylic acids was documented in two of the three patients described in the case reports; dicarboxylic aciduria was also a feature in the two sisters described by Naylor et al. (6). Deficient

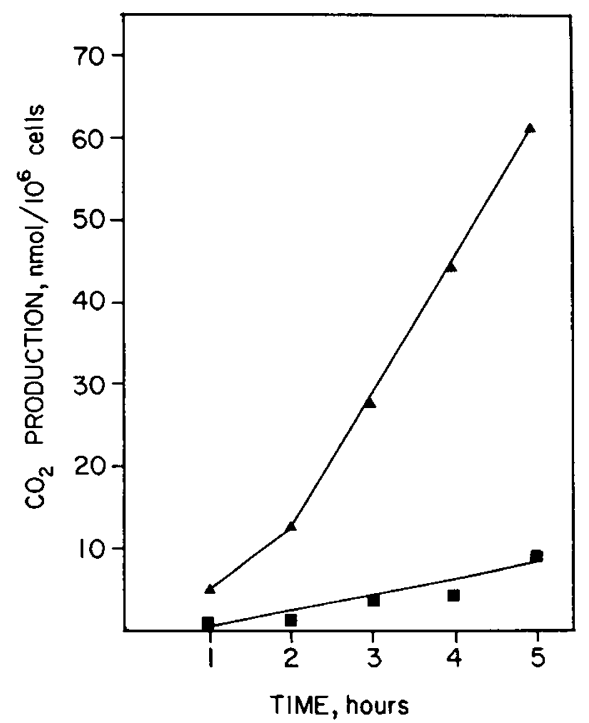

Fig. 1. Time course of $\mathrm{CO}_{2}$ production from uniformly labeled palmitate by fibroblasts. Fibroblasts from a control subject $(\boldsymbol{\Lambda})$ and patient R-1 (E) were incubated with $\left[{ }^{14} \mathrm{C}(\mathrm{U})\right]$-palmitate for $5 \mathrm{~h}$ at $37^{\circ} \mathrm{C}$. After an initial lag period, the rate of $\mathrm{CO}_{2}$ production was linear between 2 and $5 \mathrm{~h}$. The rate of $\mathrm{CO}_{2}$ production by patient R-1 fibroblasts was less than $20 \%$ of the control rate.

Table 3. Fatty acid oxidation in cultured fibroblasts*

\begin{tabular}{cccc}
\hline & Patient R-1 $\dagger$ & Controls & $(n)$ \\
\hline$\left[{ }^{14} \mathrm{C}(\mathrm{U})\right]$-palmitic acid & 3 & $15.0 \pm 1.0$ & $(4)$ \\
{$\left[1-{ }^{14} \mathrm{C}\right]$-palmitic acid } & 7.4 & $14.5 \pm 1.5$ & $(10)$ \\
{$\left[16-{ }^{14} \mathrm{C}\right]$-palmitic acid } & 0.8 & $6.3 \pm 2.1$ & $(4)$ \\
{$\left[1-^{14} \mathrm{C}\right]$-octanoic acid } & 10 & $15.1 \pm 5.7$ & $(10)$ \\
{$\left[1-^{14} \mathrm{C}\right]$-butyric acid } & 35 & $35.0 \pm 13.0$ & $(10)$ \\
\hline
\end{tabular}

${ }^{*}$ For each substrate, results are expressed as $\mathrm{nmol} \mathrm{CO}_{2}$ produced $/ 10^{6}$ cells/hr, mean \pm SD for the number of different cultures shown in parentheses.

$\dagger$ Values are the mean of three to five experiments.

activity of long-chain acyl CoA dehydrogenase was demonstrated in leukocytes and cultured fibroblasts, as well as in liver tissue from these patients. Parents of affected patients were found to have intermediate levels of long-chain acyl CoA dehydrogenase activity, consistent with an autosomal recessive mode of inheritance.

Long-chain acyl CoA dehydrogenase is one of five flavincontaining mitochondrial enzymes which dehydrogenate straight and branched-chain fatty acids as the first step in the $\beta$-oxidation cycle (15-18). The three enzymes that act on straight-chain fatty acids are relatively specific for different carbon chain lengths. In rat liver, the long-chain acyl CoA dehydrogenase is active over the range $C_{18}$ to $C_{12}$; the medium-chain enzyme from $C_{12}$ to $C_{6}$; and the short-chain enzyme from $\mathrm{C}_{6}$ to $\mathrm{C}_{4}$. Since both adipose tissue and dietary triglycerides contain predominantly $\mathrm{C}_{16}$ and $\mathrm{C}_{18}$ fatty acids, long-chain acyl CoA dehydrogenase deficiency 
effectively prevents utilization of fatty acids for either energy production or hepatic ketone synthesis. As illustrated by the case reports, the most severe manifestations of the enzyme deficiency occur during fasting when fatty acids ordinarily become the major oxidative fuel.

Many of the features of long-chain acyl CoA dehydrogenase deficiency are also seen in patients with the closely related disorder, medium-chain acyl CoA dehydrogenase deficiency (8, 19). Common features include episodes of nonketotic coma that are provoked by fasting, secondary carnitine deficiency, and dicarboxylic aciduria. It should be emphasized that most of the patients with the long-chain enzyme defect have had a much more severe illness than those with the medium-chain defect. The three cases described herein had episodes of illness beginning early in the first year and all showed signs of cardiomyopathy and chronic skeletal muscle weakness. On the other hand, the clinical description of the two sisters reported by Naylor $e t$ al. (6), indicates that their disorder was not as severe, but resembled that typically found in patients with the medium-chain enzyme defect.

The mechanism of the secondary carnitine deficiency associated with both the long- and medium-chain acyl CoA dehydrogenase deficiencies is uncertain. A similar secondary carnitine deficiency has also been observed in several other metabolic errors which block the intramitochondrial metabolism of $\mathrm{CoA}$ esters: isovaleric acidemia, propionic acidemia, and methylmalonic aciduria (20-22). It is possible that carnitine is depleted in these disorders by increased urinary excretion of carnitine esters of the nonmetabolizable fatty acids. Propionyl-carnitine has been identified in urine from patients with propionic acidemia and methylmalonic aciduria. Roe et al. at Duke University have found isovaleryl-carnitine in urine from patients with isovaleric acidemia (23), octanoyl-carnitine in medium-chain acyl CoA dehydrogenase deficiency (24), and palmityl-carnitine in one of the patients with long-chain acyl CoA dehydrogenase deficiency in the present report (personal communication). On the other hand, we have found low or normal rates of carnitine excretion in several of these defects, and speculate that a lowered renal threshold for carnitine may be part of the explanation of the secondary carnitine deficiency (20). As indicated in the case reports, we have treated two patients with long-chain acyl CoA dehydrogenase deficiency with carnitine, but are uncertain whether this was more beneficial than diet alone.

As noted above, during times of fasting stress, patients with long-chain acyl CoA dehydrogenase deficiency excrete large amounts of dicarboxylic acids in the urine. These organic acids are formed by $\omega$-oxidation of fatty acids in the cytoplasm (25). A similar dicarboxylic aciduria is also characteristic of the medium-chain acyl CoA dehydrogenase defect $(26,27)$. The presence of increased urine dicarboxylic acids and relatively low urine $\beta$-hydroxybutyrate levels is an important clue to the diagnosis of these two enzyme defects. In the two sisters in whom we have found long-chain acyl CoA dehydrogenase deficiency, Naylor et al. (6) reported that urine concentrations of $C_{12}$ and $C_{14}$ dicarboxylic acids were increased in addition to the more common $\mathrm{C}_{6}$ to $\mathrm{C}_{10}$ acids. It is possible that the presence of these longer-chain dicarboxylic acids may help to distinguish the longchain enzyme defect from the medium-chain defect.

The severe cardiomyopathy and chronic skeletal muscle weakness noted in the three patients with long-chain acyl CoA dehydrogenase deficiency (case reports) have not been associated with either of the two previously described defects early in the fatty acid oxidation pathway (carnitine-palmityl-transferase deficiency, medium-chain acyl $\mathrm{CoA}$ dehydrogenase deficiency). $\mathrm{Pa}-$ tients with carnitine-palmityl-transferase deficiency have exercise-induced muscle cramps and myoglobinuria, but no chronic weakness; patients with the medium-chain acyl $\mathrm{CoA}$ dehydrogenase deficiency usually have no detectable weakness. The differences among these three disorders suggest that the chronic muscle weakness seen in long-chain acyl CoA dehydrogenase deficiency is not simply due to impaired energy production, but may reflect a toxic effect of long-chain acyl CoA intermediates accumulated within the mitochondria. For instance, the adenine nucleotide translocase, an important site of regulation of mitochondrial oxidative phosphorylation and energy production, is very sensitive to inhibition by long-chain acyl CoA esters (28).

The fact that two of the four known surviving patients with long-chain acyl CoA dehydrogenase deficiency show evidence of permanent brain damage as a consequence of episodes of illness during the first months of life suggests that early recognition and treatment of this disorder is essential. The features of nonketotic hypoglycemia, dicarboxcylic aciduria, and carnitine deficiency may be useful clues to the diagnosis. As indicated herein, the specific enzyme defect can now be identified in a variety of tissues, including fresh leukocytes and cultured fibroblasts. Supportive dietary therapy aimed at avoiding fasting stress and minimizing the demand for fatty acid oxidation has been highly effective in avoiding recurrent attacks. Dietary therapy has also improved, but not completely eliminated, the cardiomyopathy and chronic muscle weakness in these patients.

Acknowledgments. The authors thank Richard Kelley, M.D., Ph.D. and Barbara E. Corkey, Ph.D. for their many helpful discussions and their critical review of this manuscript; Wade Hamilton, M.D., Jan Schwartz, M.D., and Dan Zeidner, M.D. of the Geisinger Medical Center (Danville, PA) for their meticulous care of patient R-1 and Judith Sondheimer, M.D. of the State University of New York, Upstate Medical Center (Syracuse, NY) for her expert care of J-1; George Booz, Teresa DeAngelis, Mark Katz, Ra-mond Spencer-Faison, and James Wright for excellent technical assistance; and Sandra Forman and Josephine Robinson for secretarial assistance.

\section{REFERENCES}

1. Bank WJ, DiMauro S, Bonilla E, Capuzzi DM, Rowland LP 1975 A disorder of muscle lipid metabolism and myoglobinuria: Absence of carnitine palmityl transferase. N Engl J Med 292;443-449

2. Chalmers RA, Lawson AM, Whitelaw A, Purkiss P 1980 Twin siblings with a Reye's-like syndrome associated with an abnormal organic aciduria, hypoglycemia, diarrhea, and vomiting with close similarities to Jamaican vomiting sickness. Pediatr Res 14:1097-1103

3. Chapoy PR, Angelini C, Brown WJ, Stiff JE, Shug AL, Cederbaum SD 1980 Systemic carnitine deficiency-a treatable inherited lipid storage disease presenting as Reye's syndrome. N Engl J Med 303:1389-1394

4. Glasgow AM, Eng G, Engel AG 1980 Systemic carnitine deficiency simulating recurrent Reye syndrome. J Pediatr 96:889-891

5. Kølvraa S, Gregerson N, Christensen E, Hobolth N 1982 In vitro fibroblast studies in a patient with $C_{6}-C_{10}$ dicarboxylic aciduria: Evidence for a defect in general acyl CoA dehydrogenase. Clin Chim Acta 126:53-67

6. Naylor EW, Mosovich LL, Guthrie R, Evans JE, Tieckelmann H 1980 Intermittent non-ketotic dicarboxylic aciduria in two siblings with hypoglycemia: An apparent defect in $\beta$-oxidation of fatty acids. J Inher Metab Dis 3:19-24

7. Rhead WJ, Amendt BA, Fritchman KS, Felts SJ 1983 Dicarboxylic aciduria: deficient $\left(11^{14} \mathrm{C}\right)$ octanoate oxidation and medium-chain acyl-CoA dehydrogenase in fibroblasts. Science 221:73-75

8. Stanley CA, Hale DE, Coates PM, Hall CL, Corkey BE, Yang W, Kelley RI, Gonzales EL, Williamson JR, Baker L 1983 Medium-chain acyl CoA dehydrogenase deficiency in children with non-ketotic hypoglycemia and low carnitine levels. Pediat Res 17:877-884

9. Coates PM, Cortner JA, Hoffman GM, Brown SA 1979 Acid lipase activity of human lymphocytes. Biochim Biophys Acta 572:225-234

10. Husain M, Steenkamp DJ 1983 Electron transfer flavoprotein from pig liver mitochondria. Biochem J 209:541-545

11. McKean MC, Beckman JD, Frerman FE 1983 Subunit structure of electron transfer flavoprotein. J Biol Chem 258:1866-1870

12. Frerman FE, Sabran JL, Taylor JL, Grossberg SE 1983 Leucine catabolism during the differentiation of 3T3-L/ cells. Expression of a mitochondrial enzyme system. J Biol Chem 258:7087-7092

13. Frerman FE, Goodman SI 1985 Fluorometric assay of acyl-CoA dehydrogenases in normal and mutant human fibroblasts. Biochem Med 33:38-44

14. Lowry OH, Rosebrough NJ, Farr AL, Randall RJ 1951 Protein measurement with the Folin phenol reagent. J Biol Chem 193:265-275

15. Ikeda Y, Tanaka K 1983 Purification and characterization of 2-methyl branched chain acyl coenzyme A dehydrogenase, an enzyme involved in isoleucine and valine metabolism, from rat liver mitochondria. J Biol Chem 258:9477-9487

16. Noda C, Rhead WJ, Tanaka K 1980 Isovaleryl CoA dehydrogenase: demonstration in rat liver mitochondria by ion enchange chromatography and 
isoelectric focusing. Proc Natl Acad Sci USA 77:2646-2650

17. Ikeda Y, Dabrowski C, Tanaka K 1983 Separation and properties of 5 distinct acyl-CoA dehydrogenases from rat liver mitochondria: Identification of a new 2-methyl branched chain acyl-CoA dehydrogenase. J Biol Chem 258:1066-1076

18. Hall CL, Kamin H 1975 The purification and some properties of electron transfer flavoprotein and general fatty acyl coenzyme A dehydrogenase from pig liver mitochondria. J Biol Chem 250:3476-3486

19. Coates PM, Hale DE, Stanley CA, Corkey BE, Cortner JA 1984 Genetic deficiency of medium-chain acyl coenzyme A dehydrogenase: studies in cultured skin fibroblasts and peripheral mononuclear leukocytes. Pediatr Res 19:671-676

20. Stanley CA, Hale DE, Whiteman DEH, Coates PM, Yudkoff M, Berry GT, Segal S 1983 Systemic carnitine deficiency in isovaleric acidemia. Pediatr Res 17:296A(abstr)

21. Roe CR, Bohan TP 1982 L-carnitine therapy in propionicacidemia. Lancet $1: 1411-1412$

22. Allen RJ, Hansch DB, Wu HLC 1982 Hypocarnitinaemia in disorders of organic acid metabolism. Lancet 2:500-50

23. Roe CR, Millington DS, Maltby DA, Bohan TP, Hoppel CL 1984 L-Carnitine enhances excretion of propionyl Coenzyme $\mathrm{A}$ as propionylcarnitine in propionic acidemia. J Clin Invest 73:1785-1788

24. Roe CR, Millington DS, Maltby DA, Bohan TP, Kahler SG, Chalbers RA 1985 Diagnostic and therapeutic implications of medium-chain acyl carnitines in the medium-chain acyl-CoA dehydrogenase deficiency. Pediatr Res (in press)

25. Truscott RJW, Hick L, Pullin C, Halpern B, Wilcken B, Griffiths H, Silink M, Kilham H, Grunseit F 1979 Dicarboxylic aciduria: the response to fasting. Clin Chim Acta 94:31-39

26. Gregersen N, Rosleff F, Kølvraa S, Hobolth N, Rasmussen K, Lauritzen R 1980 Nonketotic $\mathrm{C}_{6}-\mathrm{C}_{10}$ dicarboxylic aciduria: Biochemical investigations of two cases. Clin Chim Acta 102:179-189

27. Gregersen N, Kølvraa S, Rasmussen K, Mortensen PB, Divry P, David M, Hobolth N 1983 General (medium-chain) acyl-CoA dehydrogenase deficiency (non-ketotic dicarboxylic aciduria): quantitative urinary excretion pattern of 23 biologically significant organic acids in three cases. Clin Chim Acta 132:181-187

28. Tager JM, Wanders RJA, Groen AK, Kunz W, Bohnensack R, Kuster U, Letko G, Bohme G, Duszynski J, Wojtczak L 1983 Control of mitochondrial respiration. FEBS Lett 151:1-9

\title{
Genetic Deficiency of Medium-Chain Acyl Coenzyme A Dehydrogenase: Studies in Cultured Skin Fibroblasts and Peripheral Mononuclear Leukocytes
}

\author{
PAUl M. COATES, DANIEL E. HALE, CHARLES A. STANLEY, BARBARA E. CORKEY, AND \\ JEAN A. CORTNER \\ Departments of Pediatrics [P.M.C., D.E.H., C.A.S., J.A.C.] and Biochemistry and Biophysics [B.E.C.], University \\ of Pennsylvania School of Medicine, and Divisions of Endocrinology/Diabetes [D.E.H., C.A.S.] and Genetics
} [P.M.C., J.A.C.], The Children's Hospital of Philadelphia, Philadelphia, Pennsylvania 19104

\begin{abstract}
Medium-chain acyl coenzyme A (CoA) dehydrogenase deficiency was demonstrated in fibroblasts and/or mononuclear leukocytes from 14 patients, most of whom initially presented early in childhood with a Reyelike syndrome associated with hypoketotic hypoglycemia, dicarboxylic aciduria, and low levels of plasma carnitine. Parents of these patients had intermediate levels of medium-chain acyl CoA dehydrogenase activity, consistent with their being heterozygous for an autosomal recessive trait. All patients had normal levels of long-chain acyl CoA dehydrogenase activity, but had reduced short-chain acyl CoA dehydrogenase activity. Fatty acid oxidation was examined in cultured fibroblasts from five of the patients, using a series of ${ }^{14} \mathrm{C}$-labeled fatty acids of different chain length (palmitic, octanoic, and butyric). Oxidation of $\left[1-{ }^{14} \mathrm{C}\right]-0 c t a n o i c$ acid was less than $20 \%$ of control levels: $\left[1-{ }^{14} \mathrm{C}\right],\left[6-{ }^{14} \mathrm{C}\right]-,\left[16{ }^{14} \mathrm{C}\right]-$, and $\left[{ }^{14} \mathrm{C}(\mathrm{U})\right]-$ palmitic acid oxidation rates were $88,51,13$, and $42 \%$ of control rates,
\end{abstract}

Received November 21, 1984; accepted February 27, 1985

Address for reprints Paul M. Coates, Ph.D., Joseph Stokes, Jr. Research Institute, The Children's Hospital of Philadelphia, 34th and Civic Center Boulevard, Philadelphia, PA 19104.

Supported by NIH Grants NS17752, AMO7314, AMO1226, and RR-00240, a grant from the National Reye's Syndrome Foundation of Bryan, $\mathrm{OH}$, and a grant from the W. W. Smith Charitable Trust. respectively. $\left[1-{ }^{14} \mathrm{C}\right]$-butyric acid was oxidized normally. These data extend our previous findings of medium-chain acyl $\mathrm{CoA}$ dehydrogenase deficiency in liver tissue from three of these patients. They demonstrate the value of cultured fibroblasts and leukocytes in the diagnosis and evaluation of inherited disorders of fatty acid oxidation. (Pediatr Res 19: 671-676, 1985)

\section{Abbreviations}

CoA, coenzyme A

ETF, electron transfer flavoprotein

We recently reported three patients with a defect in ketogenesis due to deficiency of hepatic medium-chain acyl CoA dehydrogenase activity (1). The three affected patients presented with a syndrome of fasting intolerance, recurrent life-threatening episodes of hypoglycemic coma, a failure of ketogenesis, low plasma and tissue carnitine levels, and medium-chain dicarboxylic aciduria. This inherited metabolic disorder has also been demonstrated in cultured fibroblasts from patients with a similar phenotype by other investigators (2-4). 